\section{REPORTS and other PUBLICATIONS}

(not included in the monthly Books Supplement)

Great Britain and Ireland

Bulletin of the British Museum (Natural History). Entomology. Vol. 15, No. 3: Notes on the Epitolinae, Part 2. By T. H. E. Jackson. Pp. 57-80+ 8 plates. 228. Vol. 15, No. 4: On the Diptera of Nepal (Stratiornyidae, Therevidae and Dolichopidae). By David Hollis. Pp. 81-116. 138. Vol. 15, No. 5: New Species of Ugyops (Fulgoroidea: Delphacidae) from South America and South-East Asia. By R. G. Fennah. Pp. 117-132. 10s. (London: British Museum (Natural History), 1964.) Mullard Limited. Mullard Education Service. List of the Elements giving Atomic Number and Weight, Electron and Shell Dispositions, Periodic Group and Neutron Complement. Pp. 1. Educational Electronic Experi-
ments. No. 8: A Low Voltage Electrometer. Pp. 4. No. 9: A Decade ments. No. 8: A Low Voltage Electrometer. Pp. 4. No. 9: A Decade
Scaler. Pp. 7. No. 10: Hall Effect Measurements. Pp. 4. (London: Scaler. Pp. 7. No. 10: Hall Erect Measurements. Pp. 4. (London:
Mullard Limited, 1964.) International Union for Conservation of Nature. Liquid Assets. Pp. 16 (London: International Union for Conservation of Nature, 19 Belgrave
Square, 1964.) Department of Scientific and Industrial Research and the British Council. Scientific Research in British Universities and Colleges 1963-64. Pp. xxv+ 727. (London: H.M. Stationery Office, 1964.) 35s. net. The Nuffield Provincial Hospitals Trust. Sixth Report: A Record of the Progress of Schemes and Descriptions of New Projects, 1961-1964

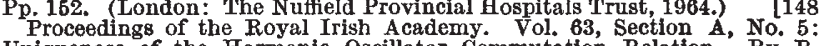
Uniqueness of the Harmonic Oscillator Commutation Relation. By $\mathbf{B}$ : Gruber and L. O'Raifeartaigh. Pp. 69-73. 1s. Vol. 63, Section B, No. 11: The Nature of the Influence of Fatty Acids, Glucose and Insulin on the Respiratory Quotient of Animal Tissues. By J. M. O'Connor. Pp. 201-216. 4s. Vol. 63, Section B, No. 12: Antitubercular Substances-19: The By C. N. O'Callaghan and Dermot Twomey. Pp. 217-224. 18. 6d. Vol. 63, Section B, No, 13: Studies on the Irish Tubificidae. By C. R. Kennedy. Pp. 225-238. 28. $6 d$. Vol. 63, Section B, No. 14: The Petrology, Chemistry By P. C. Wright. Pp. 239-264. 68. (Dublin: Hodges, Figgis and Co., Ltd.,
[1484

\section{Other Countries}

Transactions of the American Philosophical Society, New Series. Vol. 54, Alice Beardwool. Pp. 45. (Philadelphia: American Philosophical Society, Institut Royal Météorologique de Belgique. Contributions, No. 89: La Distribution de Deux Parametres Radiométéorologiques à Uccle (19571962). Par Dr. A. G. Maenhout. Pp. 8. Contributions, No. 90: Quelques Considerations Historiques et Lexicologiques sur le sens Meteorologique des Termes Brume et Brouillard. Par Dr. L. Dufour. Pp. $15 . \quad$ (Uccle-
Bruxelles: Institut Royal Météorologique de Belgique, 1964.) Conseil des Recherches Agricoles de la Province de Québec. Recherches Agronomiques: Sommaire des Résultats, 1962/1963. (Fxtrait du Rapport pour l'Année finissant lo 31 Mars 1963.) Pp. 33. (Québec: Ministère de l'Agriculture, 1963.

United States Department of the Interior: Geological Survey. Geophysical Abstracts, No. 210, July 1964. By James W. Clarke, Dorothy $B$. Vitaliano, Virginia S. Neuschel, and others. Pp. Ill +519-600, 35 cents. Water-Supply Paper 1576-E: Avalability of Ground Water in Parts of the Dinwiddle and Ward S. Motts. Pp. iv $+65+$ plates $1-3$. Water-Supply Paper 1583: Ground Water in Fountain and Jimmy Camp Valleys, EI Paso County, Colorado. By Edward D. Jenkins. Pp. $v+66+$ plates $1-5$. Water-
Supply Paper 1608-D: Artesian Water in the Malabar Coastal Plain of Supply Paper 1608-D: Artesian Water in the Malabar Coastal Plain of plates 1 and 2. Water-Supply Paper 1613-C: Sea Water in Coastai Aquifers. Robert E. Glover. Pp. iv +84. (Washington, D.C.: Government Printing Office, 1964.)
[148 United States Department of the Interior: Geological Survey. WaterSupply Paper 1681: Geology and Ground Water in the Farmington-Granby Area, Connecticut. By Allan D. Randall. Pp. vi + $129+$ plates $1-3$. WaterSupply Paper 1669-Y: Ground Water Resources of the Lowell Area, Massachusetts. By John A. Baker. Pp. iv + 37+ plates 1-3. Water-Supply Paper 1776: Geology and Ground-Water Resources of Washington, D.C. and Vicinity. By the Water by D. E. Weaver and Leonard Siu. Pp. vi $+97+$ plates 1 and 2 . Water-Supply Paper 1779-G: Geology and Ground-Water Resources of Bradley, Calhoun, and Ouachita Counties, Arkansas. By Donald $R$. Albin. Pp. ix $+32+$ plates $1-7$. Professional Paper 401: Lake P. v + 156 + plates 1-12. (Washington, D.C.: Government Printing Office 1964 .

United Nations Declaration on the Ellmination of All Forms of Racial Discrimination. Pp. 6. (New York: United Nations, 1964.) 1148 United States Department of Agriculture. Leaflet No. 389: Cantaloup
rnsects in the Southwest-How to Control Them. Prepared by O. A. Hills Insects in the Southwest-How to Control Them. Prepared by o. A. Hills
and E. A. Taylor. Pp. 8. (Washington, D.C.: Government Printing Office, 1964.) 5 cents.

Commonwealth of Australia: Department of External Affairs. Australian National Antarctic Research Expeditions. ANARE Reports, Serles A. Vol. 1: Narrative-The Exploration of Oates Land, Antarctica. By P, Law.
Pp. 67 (21 plates). (Melbourne: Antarctic Division, Department of External Affairg, 1964.) the American Museum of Natural History. Vol. 128: The Birds of Costa Rica: Distribution and Ecology. By Paul slud. Pp. $430+$ 2 plates. (New York: American Museum of Natural History, 1964.) 10 dollars. Probleme de la Séparation des Variables pour les Systemes Dynamiques a Deux et Trois Degrés de Liberté, Par Georges Mayné. Pp. 123. (Bruxolles: Académio Royale do Belgique, 1964.) 120 francs. Bulletin of the Florida State Museum (Biological Sciences). Vol. 8, No. 3: Catalogue of Fossil Birds. Part 2: (Anseriformes through Galliformes).
By Pierce Brodkorb. Pp. 195-335. (Galnesville: Florida State Museum, 1964.)

Food and Agriculture Organization of the United Nations. FAO Forestry
and
By Jonathan W. Wright. Pp. xvi + 399. (Rome: Food and Agriculture Organization of the United Nations; London: H.M. Stationery Office,
1962.) 20s.; 4 dollars. World Health Organization. The Medical Research Programme of the World Health Organization, 1958-1963: Report by the Director-General. Pp. vii +293 (Geneva: World Health Organization; London: H.M.
Stationery Office, 1964.) 18 Sw. francs; 30s.; 6 dollars. [148
Stationery Office, 1964.) 18 Sw. francs; 308 ; 6 dollars. Australia: Commonwealth Scientific and Industrial Research Organization. Land Research Series, No. 9: General Report on Lands of the West Kimberloy Area, W.A. Pp. 220+8 plates. (Melbourne: Commonwealth Scientific
and Industriai Research Organization, 1964.)
[148 United States Department of the Interior: Geological Survey. WaterSupply Paper 1580-D: Factors Affecting the Occurrence of Floods in the Southwest. By M. A. Benson. Pp. v+72+ plate 1. Water-Supply Paper 1750-A: Floods of January-February 1959 in Ohlo and Adjacent States. Prepared under the direction of E. L. Hendricks. Pp. v+ 296. (Washington,
D.C.: Government Printing Office, 1964.) Institutt for Atomenergi, Kjeller Research Establishment. Kjeller
Reports. No. 68: Extraction of Thorium and Uranium by Means of Tri-N. Octyl Amine. By J. M. P. J. Verstegen. Pp. vil +10. No. 72: Quarterly Progress Report, January-February-March 1964. Pp. v+41. No. 77: Tverbakk and J. M. Doderlein. Pp. vi +68. No. 87: Analysis of Neutron Spectra in UO, Lattices Moderated by Mixtures of Light and Heavy Water, ments of $028, \delta 25$ and Initial Conversion Ratios in Lattices of $3 \%$ Enrlched UO, Moderated by Mixtures of Light and Heavy Water. By D. C. Perricos.
Pp. vii +15 . (Kjeller: Institutt for Atomenergi, Kjeller Research Establishment, 1964)
Metropolitan Life Insurance Company. Statistical Bulletin, Vol. 45 Metropolitan Life Insurance Company. Statistical Bulletin, Vol. 45
(June 1964): Socioeconomic Status of City and Suburban Populations. Heart Disease Mortality Down Among Policyholders. Hospitalization of Children: Duration of Stay for Nonsurgical Cases, Leading Causes of Fatal Accidents. Pp. 12. (New York: Metropolitan Life Insurance Company,
[148 Bulletin of the American Museum of Natural History. Vol. 127, Article 3: A Survey of the Birds of Mongolia. By Charles Vaurie. Pp. 103-144+ 1 plate. (New York: American Museum of Natural History, 1964.) [148 of Canada. Bulletin 107: Miospores from the Mississippian Horton Group, Eastern Canada. By Geoffrey Playford. Pp. v $+47+11$ plates. 2.50 dollars. Paper 63-41: Copper and Iron Resources, Whitehorse Copper Belt, Yukon New Quebec. By F. C. Taylor and $R$. Skinner. Pp. 4.35 cents. Paper 64-8: Lac La Jannaye, Quebec-Newfoundland. By I. M. Stevenson. Pp. 5 . Paper 64-16: Geology of Charlottetown Map-Area, Prince Edward Island. By V. K. Prest. Pp. 10. 75 cents. (Ottawa: Queen's Printer, 1964.) [148 American Museum Novitates. No. 195 (Aves). By Desn Amadon. Pp. 7 . No. 2166 (February 21, 1964): Taxonomic Notes on Birds of Prey. By Dean Amadon. Pp. 24. No. 2176 (April 28, 1964): Spectrographic Analysis of Variation in the Songs of a Population of Blue-Winged Warblers (Vermi-
(V) W vora pinus). By Wesley E. Lanyon and Frank B. Gill. Pp. 18. (New York:
American Museum of Natural History, 1959 and 1964.)
[148 The American Anthropological Association. Some Foundations for publication Policy: a Report of the Publications Policy Committee to the American Anthropological Association, 1964.) Pp. 25. (Washington, D.C.: American Anthropological Association, 1964.)
Canada: Department of Mines and Technical Surveys. Geological Survey Canada: Department of Mines and Technical Surveys. Geological Survey
of Canada. Map 113A: Saint John, New Brunswick. (Ottawa: Director, of Canada. Map 113A: Saint John, New Brunswick. (Ottawa: Director,
Geological Survey of Canada, 1964.) European Atomic Energy Agency. Euratom: Scientiflc and Technical Activities. Pp. vi +210. (Brussels: European Atomic Energy Community,
[148 World Health Organization. Technical Report Series. No. 280: Biology of Human Reproduction-Report of a WHO Scientific Group. Pp. 30. $1 \mathrm{Sw}$. franc; $18.9 d$; 0.30 dollars. No. 281 : Speciflcations for the Identity sifiers, Stabillzers, Bleaching and Maturing Agents - Seventh Report of the FAO/WHO Expert Committee on Food Additives. Pp. 189. 6 Sw. francs; 108.; 2 dollars. No. 282: Human Genetics and Public Health-Second Report of the WHO Expert Committee on Human Genetics. Pp. 38. 3 Sw. francs; 58.; 1 dollar. No. 283: WHO Expert Committee on Smallpox-

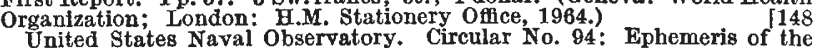
Radio Longitude of the Central Meridian of Jupiter. By B. L. Morrison Pp. 4. Circular No. 95: Provisional Ephemeris of Mars 1800-1905. By R. L. Duncombe. Pp. 82. Circular No. 96: Geocentric Distance and Velocity of Venus 1961-1970. By R. L. Duncombe, W. J. Klepczynski, and T. Van Flandern. Pp. 34. Circular No. 97: Tables of Polaris and the Equation of 1877-1967. By Victoria Meiller. Pp. 87. Circular No. 99: Astronomical Data in Machine Readable Form. By Solomon Elvove. Pp. 10. Circular No. 100: Index to United States Naval Observatory Circulars, Nos. 1-100. Pp. 7. (Washington, D.C.: United States Naval Observatory, 1964.) [148
Bulletin of the Florida State Museum (Biological Sciences). Vol. 8, No. 2: The American Cyprinid Fishes of the Subgenus Luxilus (Genus Notropis). By Carter $R$. Gubert. Pp. 95-194. (Gainesville: Florida State Museum,
[148 dollars.

$\mathrm{C}$

Editorial and Publishing Offices of "NATURE'" MACMILLAN (JOURNALS) LIMITED

ST, MARTIN'S STREET, LONDON, W.C.2

Telephone Number: Whitehall 0081. Telegrams: Phusis London W.C.2

Annual subscription: Inland $£ \mid 3$, Overseas $£|3| 5$ s., payable in advance, postage paid to any part of the world.

Advertisements only should be addressed to

T. G. Scott \& Son, Ltd., I Clement's Inn, London, W.C.2 Telephone Number: Holborn 4743

Registered as a newspaper at the General Post. Office Copyright (C) Macmillan (Journals) Limited, September 26, 1964 